\title{
THE GELATINIZATION OF NITROCELLULOSE BY PRIMARY STABILIZERS
}

Nikola Bobić ${ }^{1}$, Ljubica Totovski² ${ }^{2}$ Ljiljana Jelisavac ${ }^{2}$, Jasmina Nikolić ${ }^{3^{*}}$, Milica R. Bošnjakov ${ }^{4}$, Srđan Marković ${ }^{5}$, Saša Drmanić ${ }^{3}$

(ORIGINAL SCIENTIFIC PAPER) UDC 662.351:543.4

\footnotetext{
${ }^{1}$ Department for Defense Technologies, Ministry of Defense of the Republic of Serbia, Belgrade, Serbia

2 Military Technical Institute, Belgrade, Serbia

${ }^{3}$ Department of Organic Chemistry, Faculty of Technology and Metallurgy, University of Belgrade, Belgrade, Serbia

${ }^{4}$ Oil Refinery Belgrade, Belgrade, Serbia,

${ }^{5}$ Department of General Logistics, Ministry of Defense of the Republic of Serbia, Belgrade, Serbia
}

The examination results of the gelatinization of nitrocellulose gunpowders, stabilized by different stabilizers are described in this study. The microstructure of gunpowder samples of different chemical compositions is analyzed by the scanning electron microscopy (SEM). Apart from the three-dimensional picture of morphology and the effect of the molecular dispersion of stabilizers into the nitrocellulose matrix, the information on chemical composition of the surface of gunpowder grain was obtained by the use of energy-dispersive X-rays spectrometry on SEM (SEM/EDX). The aim of the research was the comparative analysis of three different gunpowder samples, and the estimation of the effect on the gelatinization of nitrocellulose by different stabilizers was performed including their separate influences on the chemical stability of gunpowder. The comparative analysis is based on the degree of homogenous dispersion of each stabilizer in the matrix, which has the significant positive influence on the stability of gunpowder.
Keywords: nitrocellulose, gunpowder, gelatinization, stabilizer, Akardite II.

\section{Introduction}

The capability of gelatinization is the basic condition necessary to use nitrocellulose (NC) in the production of explosives and gunpowders. Dry NC which is not gelatinized is a dangerous explosive, sensitive to friction and impact. By gelatinization of NC, the structure of a certain viscosity is obtained, and it can be shaped into grains of various dimensions, shapes, density, mechanical and ballistic properties by pressing and heating. The obtained substance burns rather slowly, controlled and in parallel layers. The stabilizer contained in gunpowder has a specific influence on the chemical evolution of gunpowder as a basic acceptor of nitrogen oxides produced by the decomposition of nitrocellulose [1-4].

The process of gelatinization is carried out by mixing the gelatinizing agent into the molecular network of nitrocellulose at high temperature with a mechanical treatment. During the process, crystal parts of the nitrocellulose structure are destroyed causing the weakening of the intermolecular forces which provide the swelling of the substance, so that the slipping of nitrocellulose chains is facilitated [5].

In order to gelatinize NC, the substance has to possess the capability of the surface interacting with NC molecules with no chemical reaction. The most widely used gelatinizing agent for the single-base gunpowder is the mixture of diethyl-ether and ethanol, and for the double-base gunpowder it is one of the active nitro esters (NG-nitroglycerine and
DEGDN - diethylene glycol dinitrate) or inert plasticizers (phthalates, triacetates, etc.).

Based on the well-known fact that solvents and gelatinizing agents are polar substances (nitro esters or substances containing the carbonyl group), the assumption was made that during gelatinization $\mathrm{NC}$ and a gelatinizing agent form dissociative compounds [1]. This hypothesis was confirmed by the acidic character of NC, contrary to the basic character of active oxygen in solvents and plasticizers. The acidic character of NC originates from the hydrogen atom bound to carbon that carries $-\mathrm{NO}_{2}$, the wellknown electron-acceptor.



Figure 1. Structure of nitrocellulose

On the other hand, nitro esters are not of basic character and they act on NC without any chemical change

\footnotetext{
* Author address: Jasmina Nikolić, Department of Organic Chemistry, Faculty of Technology and Metallurgy, University of Belgrade, Karnegijeva 4, 11000 Belgrade, Serbia

E-mail: jasmina@tmf.bg.ac.rs

The manuscript received: June,1, 2017.

Paper accepted: August, 21, 2017.
} 
of its structure. In this case, the gelatinizing agent in the electron-donor and $\mathrm{NC}$ is the acceptor through its $\mathrm{OH}$ groups.

Nowadays, in order to improve the gelatinization process, the stabilizers which also act as gelatinizing agents are widely used. For this purpose, it is necessary for the stabilizer to be dispersed inside the nitrocellulose matrix as well as possible, well soluble in NC matrix [6].

Recently, a group of aromatic compounds already used as gunpowder components showed the ability of reacting with nitrogen oxides, acting as stabilizers. Nitrogen oxides, formed during the thermal decomposition of nitrocellulose or by storage in a warehouse have an autocatalytic action on further decomposition of NC, i.e. contribute to the instability of gunpowder in the course of the period of storage. In order to improve the product stability, it is necessary to add the organic compound capable of preventing, to some extent, the NC decomposition process called stabilized. This kind of stabilizer, considered as the "secondary stabilizer" up to date, as they diminish actual decomposition effects. The introduction of the term "primary stabilizers" is currently in process, and it refers to the compounds which have the ability to prevent, stop or slow down the thermal decomposition of nitrocellulose [7].

With the aim to confirm the above described knowledge and to obtain deeper insights into the process of nitrocellulose gelatinization, the examination of the microstructure of different samples of nitrocellulose gunpowders was performed. The investigated samples were stabilized by three kinds of agents: Diphenylamine (DPA), Ethyl Centralite (EC) and Akardite II (AK II).

\section{Experimental}

The examination of the microstructure of the gunpowder samples containing different stabilizers was done using the scanning electronic microscopy (SEM). The samples were previously prepared by mechanical grinding to the grains of the surface size of about 10 to $15 \mathrm{~mm}^{2}$.

SEM analysis was performed by using the scanning electronic microscope JEOL JSM 6610 LV, with the spectrometer X-Max, Oxford Instruments, a detector surface of $20 \mathrm{~mm}^{2}$, working strain 0,3-30 kV and with the wolfram wire as the electron source [8]. The samples, previously cleaned of dust, are placed on the carrier. Taking into account that the analysis is performed under the electronic beam, the examined material is made conductive in order to be used as a cathode so that there no accumulation of charge and overheating of the samples will occur. As gunpowder is rather a weak conductor, each sample is coated with a thin layer of gold (gold coating) with the thickness of $5 \mathrm{~nm}$. Gold coating is carried out also because it gives a better contrast on the recorded image than carbon, which is also used, and therefore the more detailed image is obtained. Chemical compositions of the examined gunpowder samples (obtained from the manufacturer):
Sample NC-37 (10 years old):

Nitrocellulose

(Nitrogen in nitrocellulose... .96 .70 mas $\%$

Diphenylamine 13.10 mas \%)

Graphite. 1.50 mas $\%$

Potassium sulfate . 0.10 mas $\%$

Moisture

0.35 mas $\%$ 1.35 mas $\%$

Sample 5/12 (25 years old)

Nitrocellulose. .92 .90 mas. $\%$

(Nitrogen in nitrocellulose. 12.88 mas \%)

EC 2.00 mas \%

Potassium sulfate 1.30 mas $\%$ Camphor 3.80 mas \%

Sample EM2 (15 years old)

Nitrocellulose. .87 .00 mas. $\%$ (Nitrogen in nitrocelluose. 12.08 mas \%)

Nitroglycerine 11.20 mas $\%$

Akardite II 1.22 mas $\%$

Potassium sulfate 0.17 mas \%

Moisture. 0.41 mas $\%$

The focused beam of fast electrons of electronic microscope slides over the sample surface scanning it, and it gives the three-dimensional image of the surface morphology, as well as the information on the chemical composition of the examined part of the surface. As a consequence of the interaction of the primary electronic beam and the sample surface, different kinds of photons and electrons are emitted. By measuring the properties of these particles (direction, energy, wavelength), the information on the sample are gathered.

During the examination of the gunpowder samples, the technique of secondary electrons detection was used. These electrons are emitted by the K-orbital of gunpowder atoms due to non-elastic collisions of the focused electron beam with primary electrons [9].

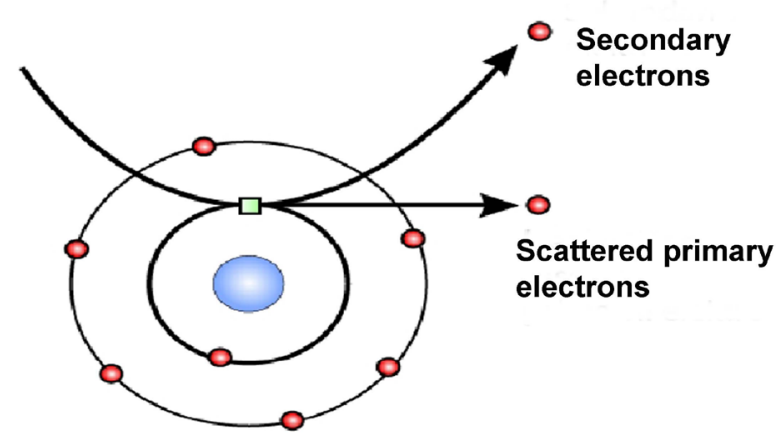

Figure 2. Formation of secondary electrons

The energy of secondary electrons is considerably low $(\approx 5 \mathrm{eV})$, and only those on the sample surface can reach the detector. The yield of secondary electrons also depends on the surface slope which is used to determine the morphology of the surface sample. The registered signal is converted into a digital form and it gives the three-dimensional image. 


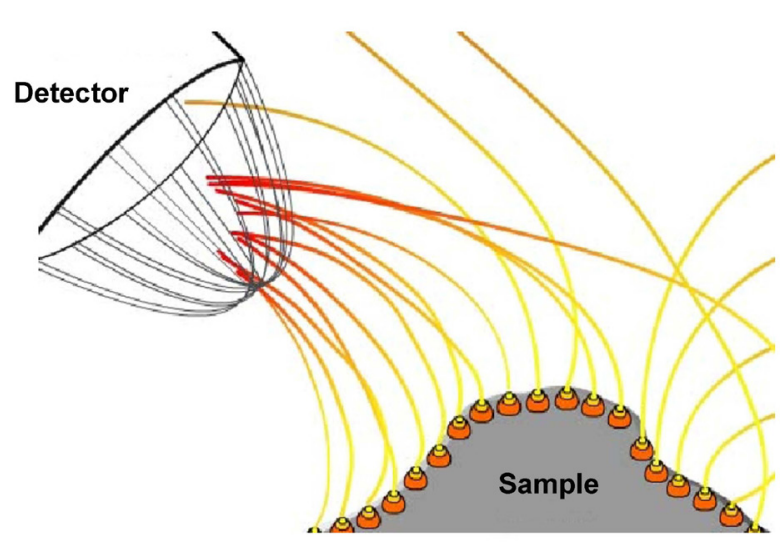

Figure 3. Morphologic measurement of a sample

The sample also electrons emit X-rays while returning from the excited to the ground state, which represents the basic method of energetic $X$-rays dispersion (Energy-Dispersive X-Rays Spectroscopy, EDX), possible only inside the electronic microscope. The emitted X-rays are analyzed and the data about the chemical structure of the sample surface are obtained, based on the fact that they are characteristic for every chemical element. When an X-ray hits the detector, the weak current is formed by the emission of electrons from the semi-conductor of the detector. By measuring this current that every X-ray produces, the X-ray energy is determined. As the output information, the EDX spectrum is obtained and it presents the number of X-rays detected on a specific energy.

\section{Results and discussion}

SEM characterization and EDX analysis

The results of the performed SEM and EDX analyses are as follows.

\section{Sample NC-37}

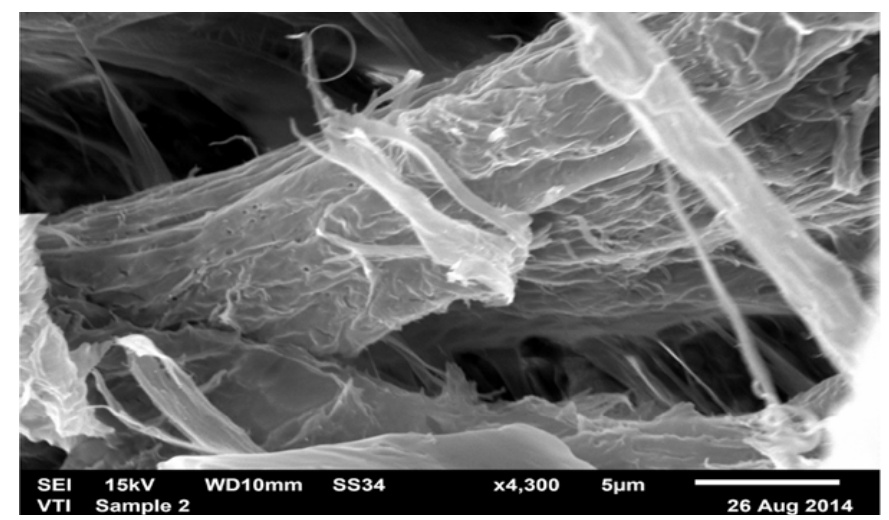

Figure 4. SEM recording of gunpowder NC-37, magnified 4.300 times

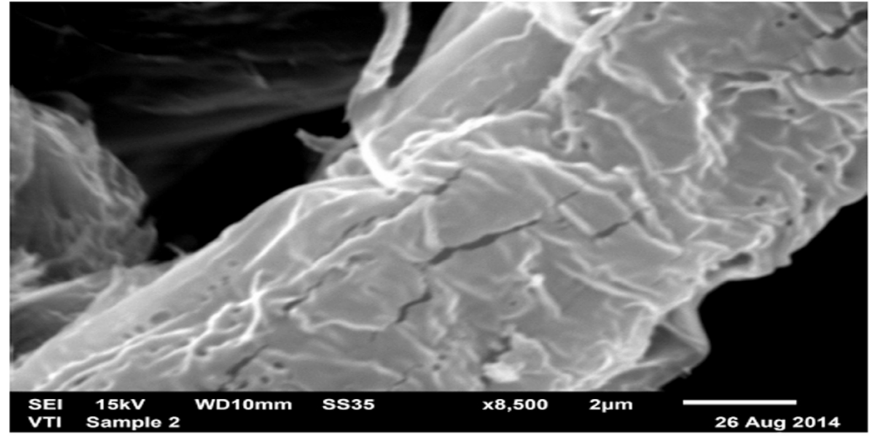

Figure 5. SEM recording of gunpowder NC-37, magnified 8.500 times

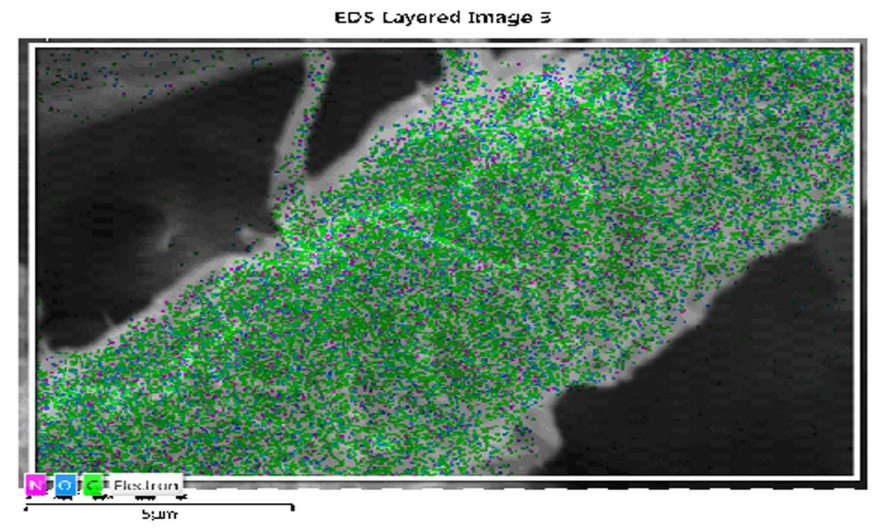

Figure 6. Gunpowder NC-37, map of element distribution (Xray mapping)



Figure 7. Gunpowder NC-37, EDX spectrum

Table 1. Gunpowder NC-37, quantitative chemical analysis

\begin{tabular}{lc}
\hline Element & $\mathrm{Wt} \%$ \\
\hline $\mathrm{C}$ & 35.90 \\
$\mathrm{~N}$ & 8.80 \\
$\mathrm{O}$ & 53.59 \\
$\mathrm{~S}$ & 0.57 \\
$\mathrm{~K}$ & 1.14 \\
Total: & 100.00 \\
\hline
\end{tabular}




\section{Sample 5/12}

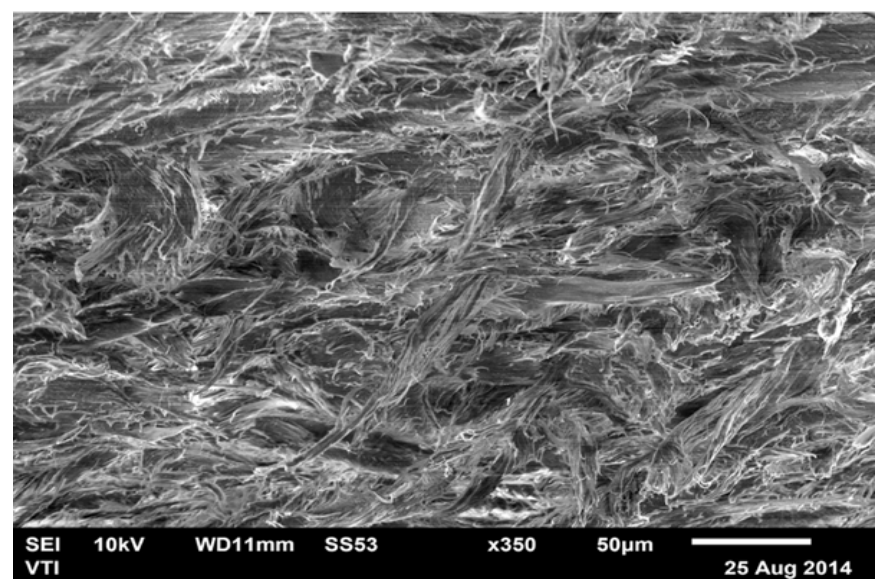

Figure 8. SEM recording of gunpowder $5 / 12$, magnified 350 times

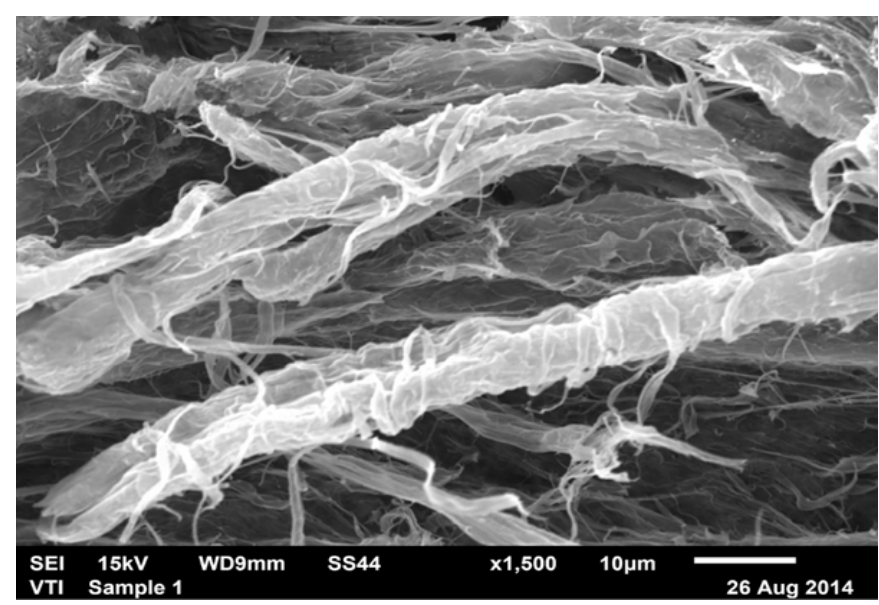

Figure 9. SEM recording of gunpowder 5/12, magnified 1500 times

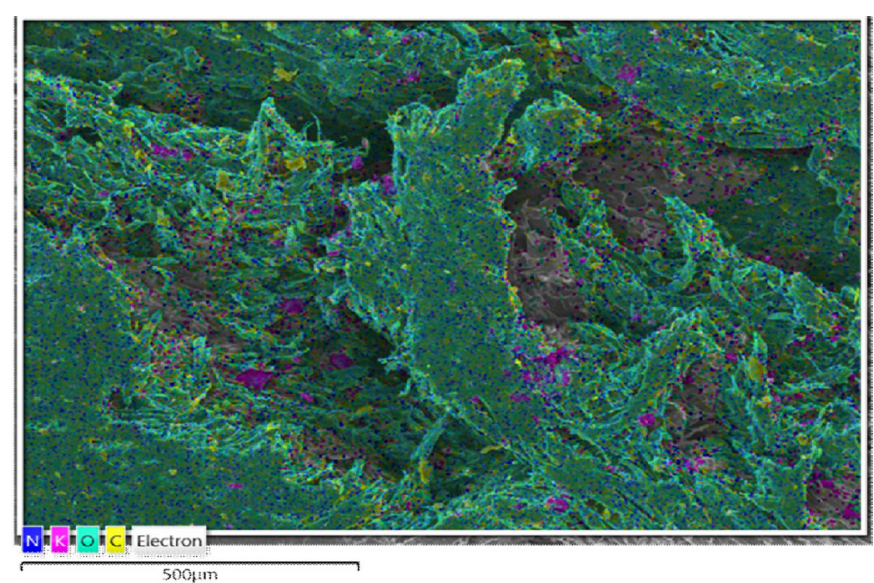

Figure 10. Gunpowder 5/12 map of element distribution (Xray mapping)



Figure 11. Gunpowder 5/12, EDX spectrum

Table 2. Gunpowder 5/12, quantitative chemical analysis

\begin{tabular}{lc}
\hline Element & $\mathrm{Wt} \%$ \\
\hline $\mathrm{C}$ & 54.08 \\
$\mathrm{~N}$ & 21.20 \\
$\mathrm{O}$ & 24.72 \\
Total: & 100.00 \\
\hline
\end{tabular}

Sample EM-2

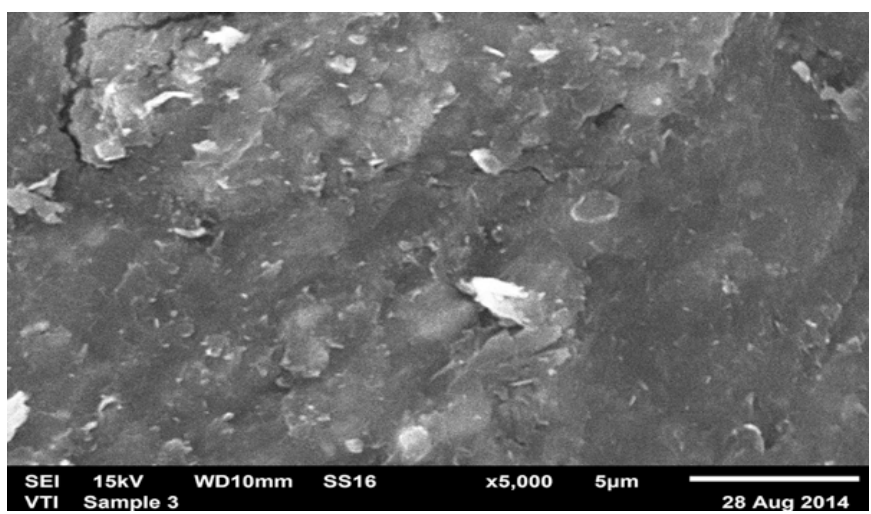

Figure 12. SEM recording of gunpowder EM-2, magnified 5.000 times

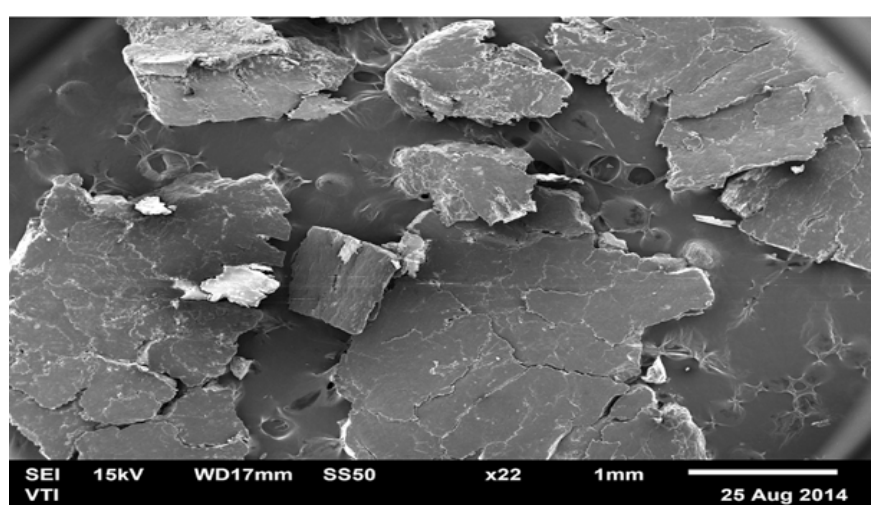

Figure 13. SEM recording of gunpowder EM-2, magnified 22 times 


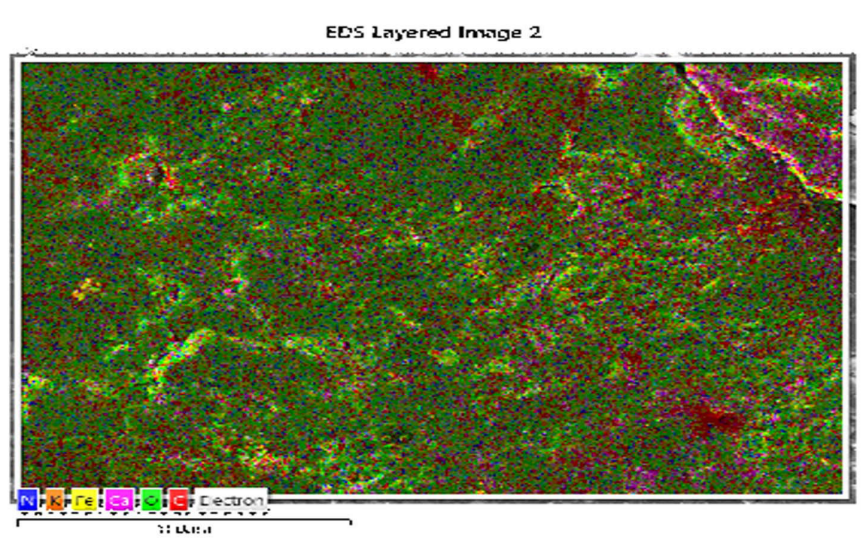

Figure 14. Gunpowder EM-2, the map of element distribution (X-ray mapping)

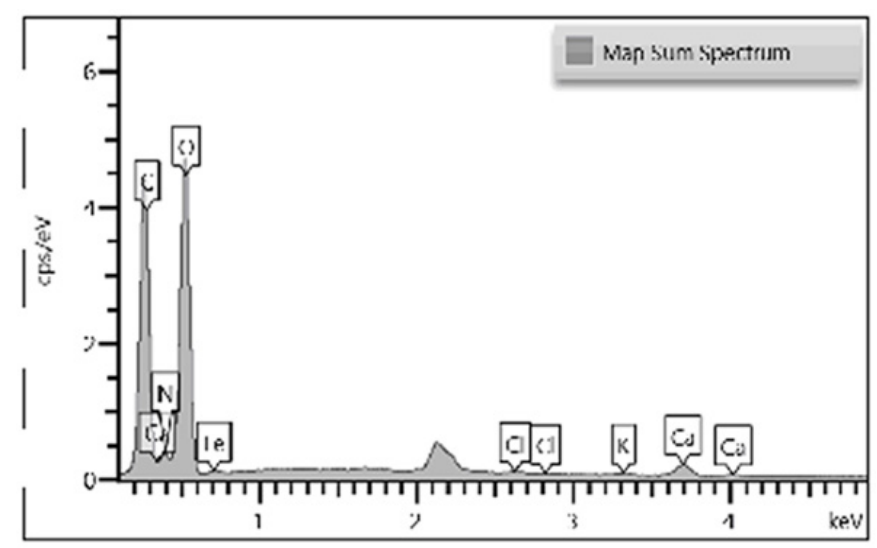

Figure 15. Gunpowder EM-2, EDX spectrum

Table 3. Gunpowder EM-2, quantitative chemical analysis

\begin{tabular}{lr}
\hline Element & \multicolumn{1}{c}{$\mathrm{Wt} \%$} \\
\hline $\mathrm{C}$ & 39.57 \\
$\mathrm{~N}$ & 4.51 \\
$\mathrm{O}$ & 52.71 \\
$\mathrm{Cl}$ & 0.20 \\
$\mathrm{~K}$ & 0.25 \\
$\mathrm{Ca}$ & 1.57 \\
$\mathrm{Fe}$ & 1.19 \\
Total: & 100.00 \\
\hline
\end{tabular}

The signals from the gunpowder samples were collected so that the insight into the position/distribution of the gelatinization agent on the carrier can be obtained. In that way, from the results of secondary electrons (SE) and backscattered electrons recordings, EDX spectrum and the table of the results of the quantitative chemical analysis were obtained.

The morphology of the samples was deduced and presented by SEM images (Figures 4, 5, 8, 9, 12 and 13), obtained by the voltage combination of $10 \mathrm{kV}-15 \mathrm{kV}$.
It can be observed that the sample EM2, containing Akardite II as a stabilizer possesses the most compact microstructure. In other words, the highest degree of the homogenous dispersion of a stabilizer in the NC matrix. The stabilizer named Ethyl Centralite also shows a considerable dispersion level, but not as good as Akardite II. Sample NC-37, where NC was treated by diphenylamine has the lowest degree of stabilizer dispersion, which points to the conclusion that diphenylamine stays on the surface of nitrocellulose. Contrary to that, Akardite II and Ethyl Centralite pierce into the matrix, which shows they are soluble by NC.

The map distribution of selected elements (X-ray mapping) on the specific surface of each gunpowder sample is shown in Figures 6,10 and 14. The choice of the number and sort of elements, each of them marked with the appropriate color, enables the overview on the homogeneity/heterogeneity of stabilizer dispersion. The prevailing colors represent the most widely spread elements on the chosen surface of the examined gunpowder sample - carbon, oxygen and nitrogen. Sulfur, potassium, iron and gold are present in smaller percentage, which confirms the theoretical chemical composition. The most homogenous sample is EM2, (containing Akardite II), followed by the sample 5/12, while the sample NC-37 containing diphenylamine stabilizer is proved to be the least homogenous. The obtained EDX spectra (Figures 7,11 and 15) have confirmed the purity of all examined samples. $Y$ axis on the EDX spectrum represents the energy of the X-rays in $\mathrm{keV}$, and the peak positions establish the presence of chemical elements, in other words, the results of the quantitative chemical analysis. $X$ axis shows the peak intensity (in impulse counts) depending on the specific element concentration.

As for the sample 5/12 EDX, the spectrum is obtained based on the mostly abundant elements (carbon, oxygen, nitrogen), while for samples NC-37 and EM-2 also less abundant elements are taken into consideration (potassium, sulfur), but not those derived directly from the gunpowder mass (gold, iron). The quantitative chemical analysis (Tables 1-3) is based on the $X$ axis values of the EDX spectrum, which are directly related to the concentration of the present elements. The presented data refer to the concentration as mass parts of separate elements from which K-orbitals emitted secondary electrons, due to non-elastic collisions with primary beam electrons.

\section{Conclusions}

The effect of the gunpowder stabilizers used in this research is determined by a range of factors. However, the ability of a stabilizer to gelatinize nitrocellulose holds an especially significant place among them. The most often used stabilizer, namely diphenylamine, reacts at the surface with nitrogen oxides when they appear. During their migration from the place of formation inside the NC matrix to the surface, the part of produced nitrogen 
oxides and free radicals already negatively influence the matrix and catalytically force further decomposition, so that the stabilizer on the surface does not react with them all.

Being able to penetrate into the NC matrix and create a homogenous intermolecular dispersion, in other words gelatinization, makes Akardite II a very efficient stabilizer. It reacts with the traces of nitro and sulphonyl groups that came from nitric and sulfuric acid in the NC production, and prevents the forming of oxides. All this points to the fact that Akardite II can be a successful replacement for diphenylamine as a stabilizer. Besides that, the presence of substances that act as quality gelatinizing agents, slow down the degradation of NC therefore removing the need for a secondary stabilizer (diphenylamine and derivatives).

As the gelatinization of a stabilizer at room temperature is an important factor for gunpowder stability, it is explained why many methods for predicting the necessary stabilizer quantity suggested too high values of gunpowder lifetime [10-14]. Those methods are based on the regression analysis from the results obtained at high temperatures, considerably above the melting point of a stabilizer $[15,16]$. Any kind of a stabilizer is much more efficient in a liquid phase, and that is the reason for the difference between the calculated and experimentally determined lifetimes.

Different sorts of gunpowder were compared in this research with the aim to obtain the generalized picture.

\section{Acknowledgments}

Authors are grateful to the Ministry of Defense and the Ministry of Education, Science and Technological Development of the Republic of Serbia for financial support (Project 172013).

\section{References}

[1] T. Lindblom, Reactions in Stabilizer and Between Stabilizer and Nitrocellulose in Propellants, Propellants Explosives Pyrotechnics 27 (2002) 197-208.

[2] Y. Wu, Y. Lin, Z. Ghe, Properties and Application of a Novel Type of Glycidyl Azide Polymer (GAP)-Modified Nitrocellulose Powders, Propellants Explosives Pyrotechnics 40 (2015) 67-73.

[3] Y.I. Rubtsov, A.I. Kazakov, D.B. Lempert, G.B. Manelis, Kinetic Regularities of the Heat Release for the Interaction of Some Organic Compounds with Ammonium Nitrate Propellants Explosives Pyrotechnics 31 (2006) 421-434.

[4] S. Wilker, G. Heeb, B. Vogelsanger, J. Petržílek, J. Skládal, Triphenylamine - a 'New' Stabilizer for Nitrocellulose Based Propellants - Part I: Chemical Stability Studies, Propellants Explosives Pyrotechnics 32 (2007) 135-148.

[5] P.Maksimović, Eksplozivne materije. Beograd; Vojnoizdavački zavod; 1985.

[6] J. Wilken, Osnove stabilnosti municije, interna publikacija UNDP-SEESAC, Sarajevo; Mašinski fakultet; 2011.

[7] S. Stoiljković, Osnove dijagnostikovanja i praćenja stanja kvaliteta municije, sa Tehničkog seminara Bezbednost u radu sa ubojnim srEDXtvima, skladištenje, čuvanje, uništavanje ubojnih srEDXtava, Kragujevac, Srbija, 2012.

[8] SubsTech, Substances \& Technologies, www.substech.com/dokuwiki/doku.php?id=scanning_ electron_microscope (02. 01. 2016.)

[9] Lj. Đačanin, Optičke i strukturne osobine prahova cinksilikata dopiranih jonima retkih zemalja i prelaznih metala, Magistarski rad, PMF Novi Sad, 2009.

[10] Lj. Jelisavac, Unapređenje sistema kontrole hemijske stabilnosti baruta i raketnih goriva, Doktorska disertacija, Vojna akademija Beograd, 2013.

[11] Lj. Jelisavac, Hemijska stabilnost i vek upotrebe baruta i RG, Kumulativna naučno -tehnička informacija 2, VTIBeograd, 2009.

[12] Standard odbrane Republike Srbije SORS 8069/91: Praćenje hemijske stabilnosti baruta i raketnih goriva. Beograd 1991.

[13] STANAG 4117 PPS: Explosives, Stability Test Procedures and Requiremients for Propellants Stabilized with Diphenylamine, Ethyl Centralite or Mixture of Both, Ed. 3 Mas/68-Pps/4117. Brussels. 1998

[14] STANAG 4582: Explosives, nitrocellulose based propellants - stability test procedures and requirements using HFC Brussels: North Atlantic Treaty Organization. Military Agency for Standardization. 2004.

[15] STANAG 4527: Explosive, Chem. Stab.: NC Based Propellants, Procedure for Assessment of Chemical Life and Temperature Dependence of Stabilizer Consumption Rates Brussels: North Atlantic Treaty Organization. Military Agency for Standardization. 2004.

[16] AOP-48: Explosives, Nitrocellulose Based Propellants - Stability Test Procedures and Requirements Using Stabilizer Depletion, Ed.2. North Atlantic Treaty Organization. Military Agency. Brussels. 2008. 
Izvod

\section{ŽELATINIZACIJA NITROCELULOZE PRIMARNIM STABILIZATORIMA}

Nikola Bobić ${ }^{1}$, Ljubica Totovski², Ljiljana Jelisavac² ${ }^{2}$ Jasmina Nikolić $^{3}$,

Milica R. Bošnjakov ${ }^{4}$, Srđan Marković ${ }^{5}$, Saša Drmanić ${ }^{3}$

1Odeljenje za odbrambene tehnologije, Ministarstvo odbrane Republike Srbije, Beograd, Srbija UDK 662.351:543.4

${ }^{2}$ Vojnotehnički institut, Beograd, Srbija

3 Katedra za organsku hemiju, Tehnološko-metalurški fakultet Univerziteta u Beogradu, Beograd, Srbija

${ }^{4}$ Rafinerija nafte Beograd, Beograd, Srbija

5 Odeljenje za opštu logistiku, Ministarstvo odbrane Republike Srbije, Beograd, Srbija

$U$ radu su prikazani rezultati ispitivanja želatinizacije nitroceluloznih baruta, stabilisanih različitim tipovima stabilizatora. Pomoću skenirajuće elektronske mikroskopije (Scanning Electron Microscopy, SEM) ispitivana je mikrostruktura uzoraka baruta različitog hemijskog sastava. Pored trodimenzionalne slike topografije i učinka molekularne disperzije stabilizatora u matricu nitroceluloze, pomoću metode energetske diperzije X-zraka (Energy-Dispersive X-Rays Spectroscopy - EDX) dobijena je informacija o kvantitativnom i kvalitativnom hemijskom sastavu ispitivanog dela površine barutnog zrna. Na osnovu komparativne analize, izvršena je ocena efekta želatinizacije nitroceluloze različitim tipovima stabilizatora i njihov pojedinačni uticaj na hemijsku stabilnost baruta.

Ključne reči: Nitroceluloza, baruti, želatinizacija, stabilizator, akardit II 